\title{
Effects of Sb Addition on Microstructural Evolution and Mechanical Properties of Mg-9Al-5Sn Alloy
}

\author{
Chun-Hua Ma ${ }^{1,2} \cdot$ Fu-Sheng Pan ${ }^{1} \cdot$ Ding-Fei Zhang ${ }^{1} \cdot$ Ai-Tao Tang ${ }^{1} \cdot$ Zhi-Wen Lu $^{2}$
}

Received: 28 November 2019 / Revised: 9 February 2020 / Published online: 3 June 2020

(c) The Chinese Society for Metals (CSM) and Springer-Verlag GmbH Germany, part of Springer Nature 2020

\begin{abstract}
The Mg-9Al-5Sn- $x \mathrm{Sb}(x=0.0,0.3,0.6,1.0,1.5 \mathrm{wt} \%)$ alloys were prepared by a simple alloying process followed by hot extrusion with an extrusion ratio of 28.2. The effects of $\mathrm{Sb}$ additions on the microstructure and mechanical properties of the Mg-9Al-5Sn alloys were investigated by optical microscopy, X-ray diffraction, transmission electron microscopy, scanning electron microscopy equipped with an energy-dispersive X-ray spectrometer. The results indicated that the phases $\alpha-\mathrm{Mg}$ matrix, $\mathrm{Mg}_{2} \mathrm{Sn}, \mathrm{Mg}_{3} \mathrm{Sb}_{2}$ and $\mathrm{Mg}_{17} \mathrm{Al}_{12}$ exist in the as-cast $\mathrm{Sb}$-containing alloys. Sb addition results in the precipitation of $\mathrm{Mg}_{3} \mathrm{Sb}_{2}$. The dendritic size of these alloys decreases with the addition of Sb. Both their ultimate tensile strength and yield strength of extruded alloys increase, and their elongation decreases gradually with increasing the content of Sb. The better mechanical properties of the as-extruded alloys were achieved due to the refined grains and the formation of dispersive second phases $\mathrm{Mg}_{3} \mathrm{Sb}_{2}$
\end{abstract}

Keywords $\mathrm{Mg}-\mathrm{Al}-\mathrm{Sn}-\mathrm{Sb}$ alloy $\cdot$ Microstructure $\cdot$ Extrusion $\cdot$ Second phase $\cdot$ Mechanical properties

\section{Introduction}

Mg-based alloys own excellent properties with high strength, low density, favorable machinability, recycling capability and high ductility. They have been extensively applied in the biomedicine, aerospace and automotive industries [1-5]. The increasing demand for automobile weight reduction has led to the development of magnesium alloys with higher strength [6-8]. Mg and its alloys are one of the lightest structural materials. However, they have relatively low strength and ambient formability which limits their further applications $[9,10]$. Previous efforts were taken to improve such mechanical properties of $\mathrm{Mg}$ by alloy design and processing optimization [11-14].

$\mathrm{Mg}-\mathrm{Al}$ alloys are typical widely used commercial magnesium alloys under intensive investigations [15-19].

Available online at http://link.springer.com/journal/40195.

Ding-Fei Zhang

zhangdingfei@cqu.edu.cn

1 College of Materials Science and Engineering, Chongqing University, Chongqing 400045, China

2 College of Mechanical and Electronic Engineering, Nanyang Normal University, Nanyang 473061, China
Currently, the magnesium alloys based on $\mathrm{Mg}-\mathrm{Al}$ based alloys are widely studied, have gained great achievements [20-23]. The addition of alloying element in $\mathrm{Mg}$ could result in the formation of $\mathrm{Mg}_{3} \mathrm{Sb}_{2}$ phase [24]. The existence of such phase modifies the mechanical properties of magnesium alloys. The previous results [25] show that the creep properties of as-cast AZ91 alloy were significantly improved by adding $\mathrm{Sb}$ element. The addition of $\mathrm{Sb}$ changed the morphology of intermetallic phase of $\mathrm{Mg}_{2} \mathrm{Si}$ from Chinese script to a polygonal shape, leading to the improvement of mechanical properties. The responsible mechanism is that the polygonal-type $\mathrm{Mg}_{2} \mathrm{Si}$ particles preferentially nucleated at $\mathrm{Mg}_{3} \mathrm{Sb}_{2}$ particles [26-28]. Sn and $\mathrm{Si}$ elements belong to the same group of elements in the periodic table of elements. $\mathrm{Mg}-\mathrm{Sn}$-based magnesium alloys with a certain amount of Sn content have received considerable attention owing to their excellent potential $[29,30]$. Mg can interact with $\mathrm{Sn}$ to form $\mathrm{Mg}_{2} \mathrm{Sn}$ phase. The addition of $\mathrm{Sb}$ element has led to a favorable microstructure by distributing the fine $\mathrm{Mg}_{3} \mathrm{Sb}_{2}$ particles at the grain boundary and refines the $\mathrm{Mg}_{17} \mathrm{Al}_{12}$ precipitates, thus improving tensile properties [28]. The thermally stable $\mathrm{Mg}_{3} \mathrm{Sb}_{2}$ phase is formed by adding $\mathrm{Sb}$ to magnesium alloys, which mainly distributes along grain boundaries, thus improving the strength and creep resistance of the 
alloys at ambient and elevated temperatures [31]. Some researchers studied the strengthening mechanism, reported that adding $\mathrm{Sb}$ element could significantly refine the grain size of a-Mg matrix phase due to the $\mathrm{Mg}_{3} \mathrm{Sb}_{2}$ phases, acting as the heterogeneous nucleation sites of the melt [32, 33].

There is therefore clearly a need to further improve the mechanical properties of $\mathrm{Mg}$ alloys through the development of new alloy systems if they can provide a commercially viable alternative to steel and $\mathrm{Al}$ alloy [34]. Numerous investigations were carried out in searching for suitable Mg alloy systems with enhanced properties. It has been established that the additions of rear earth (RE) elements could improve the mechanical properties of magnesium alloys remarkably [35-39]. However, RE addition can result in the increment of cost. It is therefore necessary to find other elements to substitute the REs for improving the performance of magnesium alloys. The $\mathrm{Mg}-\mathrm{Sn}$ system is known as a typical precipitation system. Tin element has a high solid solubility in $\mathrm{Mg}$ at the eutectic temperature [40-42]. In this system, the main second phase is $\mathrm{Mg}_{2} \mathrm{Sn}$ with a melting temperature of about $770.5^{\circ} \mathrm{C}$. The investigations on the addition of $\mathrm{Sn}$ to the $\mathrm{Mg}-\mathrm{Al}$ and $\mathrm{Mg}-\mathrm{Zn}$ system magnesium alloys have received considerable attentions [43-46]. Sn element has several excellent roles as an alloying element in $\mathrm{Mg}$ for elevated temperature applications [47-50]. Previous investigations on the microstructure and mechanical properties of as-cast $\mathrm{Mg}-\mathrm{Sn}$ alloys show that $\mathrm{Sn}$ addition could reduce the secondary dendrite arm spacing of the $\alpha-\mathrm{Mg}$ phase. The binary $\mathrm{Mg}-5 \mathrm{Sn}$ alloy exhibited the best mechanical properties, mainly due to the formation of dispersive $\mathrm{Mg}_{2} \mathrm{Sn}$ phase in the Mg matrix [51,52].

Up to now, there is no research on the effect of Sb addition on the microstructure, texture and mechanical properties of the $\mathrm{Mg}-\mathrm{Al}-\mathrm{Sn}$ alloys. A systematic investigation on the effects of $\mathrm{Sb}$ addition on the microstructure and mechanical property of $\mathrm{Mg}-\mathrm{Al}-\mathrm{Sn}$ alloys is needed for the development of new high-performance wrought magnesium alloy materials. It has been reported that the texture strengthening was the main reason for improving strength and ductility values $[53,54]$. The RE elements are the high cost at commercial level which can reduce texture intensity; therefore, economical alloying elements need to be searched out for similar working features. So far, calcium revealed some characteristics similar to RE alloys as proposed by the literature $[55,56]$. In this respect, based on these studies, as a major objective, our present work goals provide a deeper understanding of the influence of texture intensity of $\mathrm{Sb}$ on the microstructure and mechanical properties of the $\mathrm{Mg}-\mathrm{Al}-\mathrm{Sn}$ magnesium alloys. In this work, the influence of $\mathrm{Sb}$ addition on the structure and mechanical properties of $\mathrm{Mg}-9 \mathrm{Al}-5 \mathrm{Sn}$ alloy was studied.

\section{Experimental}

The alloys with different nominal compositions of $\mathrm{Mg}-9 \mathrm{Al}-5 \mathrm{Sn}-x \mathrm{Sb}(x=0.0,0.3,0.6,1.0,1.5 \mathrm{wt} \%)$ were prepared by melting in a vacuum induction furnace using commercially pure $\mathrm{Mg}$ (99.90 wt\%), pure $\mathrm{Al}$ (99.95 wt\%), pure Sb (99.95 wt\%), pure Sn (99.90 wt\%), under an $\mathrm{Ar}$ atmosphere. After the melt was homogenized at $750{ }^{\circ} \mathrm{C}$ for $10 \mathrm{~min}$, the composition analysis of each cast alloy was conducted on the X-ray fluorescence (XRF) spectrometer (LAB CENTER XRF-1800 CCDE) (Table 1). The homogenization treatments of ingots were held at $420{ }^{\circ} \mathrm{C}$ for $12 \mathrm{~h}$ followed by air cooling. The homogenization temperature was determined according to the relevant binary and ternary phase diagrams. Before hot extrusion, the alloy ingot and extrusion die were preheated at $300{ }^{\circ} \mathrm{C}$ for $2 \mathrm{~h}$. The homogenized ingots with a diameter of $80 \mathrm{~mm}$ were extruded to rods with a diameter of $16 \mathrm{~mm}$ at $300{ }^{\circ} \mathrm{C}$. The extrusion ratio was 28.2 , and the average extrusion speed was $10 \mathrm{~mm} / \mathrm{s}$.

The tensile tests were carried out for the as-extruded samples by the SANSCMT-5105 electronic testing machine at a strain rate of $3 \mathrm{~mm} / \mathrm{min}$ at room temperature. The tensile specimens have a cross-sectional diameter and a gauge length of $5 \mathrm{~mm}$ and $35 \mathrm{~mm}$, respectively. The tensile axis was parallel to the extrusion direction (ED). Tensile properties were determined based on the complete stress-strain curves. The yield strength (YS) was calculated according to the stress value at a standard offset strain of $0.2 \%$, and the fracture elongation was obtained as the percent of elongation over the gage length. For each data, at least three tensile tests were performed.

The microstructures of specimens were characterized by an optical microscope of Axio Vert A1 (CARL ZEISS) metallographic microscope (OM). The identification of second phases was carried out on a Rigaku D/MAX-2500PC diffractometer using a $\mathrm{Cu} K \alpha$ radiation and graphite monochromator operated at $40 \mathrm{kV}$ and $200 \mathrm{~mA}$, with a scanning angle range from $10^{\circ}$ to $90^{\circ}$ and at a scanning speed of $2^{\circ}$ min. The Materials Data Inc. Software Jade 5.0 software [57], a Powder Diffraction File (PDF release 2002) [58] and Pearson's Handbook of Crystallographic Data were used

Table 1 Chemical compositions of the $\mathrm{Mg}-9 \mathrm{Al}-5 \mathrm{Sn}-x \mathrm{Sb}$ alloys

\begin{tabular}{lrlll}
\hline Samples & \multicolumn{4}{l}{ Composition (wt\%) } \\
\cline { 2 - 5 } & \multicolumn{1}{c}{$\mathrm{Al}$} & $\mathrm{Sn}$ & $\mathrm{Sb}$ & $\mathrm{Mg}$ \\
\hline Mg-9Al-5Sn & 10.1971 & 5.1017 & 0.0000 & Bal. \\
Mg-9Al-5Sn-0.3Sb & 9.7530 & 5.0231 & 0.1856 & Bal. \\
Mg-9Al-5Sn-0.6Sb & 9.7530 & 5.0231 & 0.5184 & Bal. \\
Mg-9Al-5Sn-1.0Sb & 9.7804 & 4.8612 & 0.7112 & Bal. \\
Mg-9Al-5Sn-1.5Sb & 9.7413 & 4.9465 & 0.9664 & Bal. \\
\hline
\end{tabular}


to analyze the XRD data. The microstructural morphology and compound composition of the alloys were examined by scanning electronic microscope (SEM) (TESCAN VEGA 3 LMH) equipped with an Oxford INCA Energy 350 energydispersive X-ray (EDS) spectrometer and a Tecnai G2 F20 S-TWIN $(200 \mathrm{kV})$ transmission electron microscope (TEM) equipped with energy-dispersive X-ray (EDX) spectrometer. The as/extruded samples for the OM and SEM observation were prepared by mechanical grinding from 800 grit down to 4000 grit followed by etched in a solution of $1 \mathrm{~g}$ picric acids, $16 \mathrm{ml}$ ethanol and $2.6 \mathrm{ml}$ acetic acids. The as-cast samples were etched by immersing in a solution of $2 \mathrm{ml}$ nitric acid and $98 \mathrm{ml}$ ethanol for 10-20 s. Vickers hardness testing for the aging treated samples was carried out under a load of $50 \mathrm{~g}$ and dwell time of $60 \mathrm{~s}$.

\section{Results and Discussion}

\subsection{Microstructures of As-Cast Mg-9AI-5Sn-xSb Alloys}

The microstructures of the as-cast $\mathrm{Mg}-9 \mathrm{Al}-5 \mathrm{Sn}-x \mathrm{Sb}$ alloys are presented in Fig. 1. These alloys exhibit a typical dendritic structure. They have continuously netlike eutectics at $\alpha-\mathrm{Mg}$ grain boundaries. A large number of plate-like and irregular block second phase locate at grain boundaries and inside the grains. The literature [59] has showed the addition of $0.5 \% \mathrm{Sb}$ can somewhat refine the grains of as-cast $\mathrm{Mg}-10 \mathrm{Al}$ alloys, and the $\mathrm{Mg}_{3} \mathrm{Sb}_{2}$ phase promoted the grain refinement during equal channel angular pressing (ECAP) and prevented crack propagation during the tensile testing. Alloy 1\# with free of Sb shows the coarsest grain (Fig. 1a) and alloy 4\# containing Sb the finest grain (Fig. 1d). It can be seen that the grain refines and the volume fraction of second phase increases gradually with Sb content increasing. The addition of $\mathrm{Sb}$ into $\mathrm{Mg}-\mathrm{Al}-\mathrm{Sn}$ alloys cannot suppress the formation of $\mathrm{Mg}_{17} \mathrm{Al}_{12}$ phase.

In order to analyze the intermetallic compounds, XRD and EDS analysis were carried out (Figs. 2, 3, 4). Typical EDS spectra taken from the particles and $\alpha-\mathrm{Mg}$ matrix of the as-cast alloy $5 \#$ indicate that almost all second phase consists of Mg. Combining with the peak indexing in the XRD pattern (Fig. 4), it can be concluded that the major phases in the as-cast alloy $5 \#$ are $\mathrm{Mg}_{3} \mathrm{Sb}_{2}, \mathrm{Mg}_{2} \mathrm{Sn}$ and $\mathrm{Mg}_{17} \mathrm{Al}_{12}$ phase.

Figure 2 shows the XRD patterns of as-cast $\mathrm{Mg}-9 \mathrm{Al}-5 \mathrm{Sn}-x \mathrm{Sb}$ alloys. The structure and amount of alloy phases changed with the increasing of $\mathrm{Sb}$ content. The as-cast $\mathrm{Mg}-9 \mathrm{Al}-5 \mathrm{Sn}-x \mathrm{Sb}$ alloys mainly consisted of $\alpha-\mathrm{Mg}, \mathrm{Mg}_{2} \mathrm{Sn}, \mathrm{Mg}_{3} \mathrm{Sb}_{2}$ and $\mathrm{Mg}_{17} \mathrm{Al}_{12}$ phases. The as-cast Sb-free 1\# alloy is mainly composed of $\alpha-\mathrm{Mg}, \mathrm{Mg}_{2} \mathrm{Sn}$ and $\mathrm{Mg}_{17} \mathrm{Al}_{12}$ phases. In contrast, the $\mathrm{Sb}$-containing alloys have additional diffraction peaks corresponding to $\mathrm{Mg}_{3} \mathrm{Sb}_{2}$ phase. The $\mathrm{Mg}_{3} \mathrm{Sb}_{2}$ phase (Structure type of $\mathrm{La}_{2} \mathrm{O}_{3}$, Pearson symbol hp5, and Space Group P-3m1) has a close-packed hexagonal structure same as that of $\alpha-\mathrm{Mg}$. As the $\mathrm{Sb}$ content increases, the diffraction intensity of $\mathrm{Mg}_{3} \mathrm{Sb}_{2}$ phase increases gradually.

The XRD pattern of the as-cast $5 \#$ alloy corresponds to four phases: $\alpha-\mathrm{Mg}, \mathrm{Mg}_{2} \mathrm{Sn}, \mathrm{Mg}_{17} \mathrm{Al}_{12}$ and $\mathrm{Mg}_{3} \mathrm{Sb}_{2}$ phase (Fig. 3). The backscatter electron (BSE) images of this alloy are shown in Fig. 4. Apparently, three types of

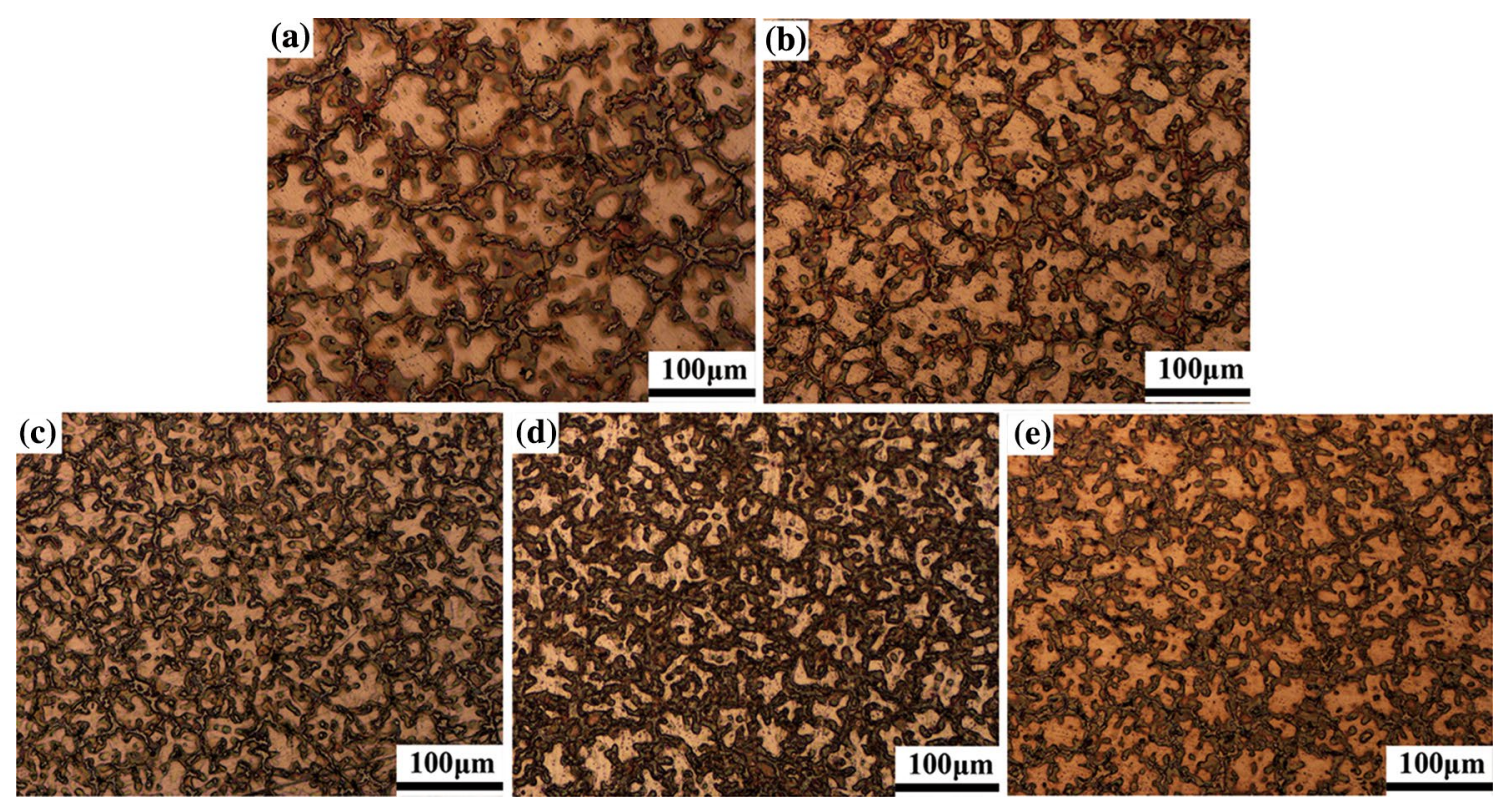

Fig. 1 Optical micrographs of the as-cast Mg-9Al-5Sn- $x \mathrm{Sb}$ alloys: $\mathbf{a} x=0.0, \mathbf{b} x=0.3, \mathbf{c} x=0.6, \mathbf{d} x=1.0$, e $x=1.5$ 


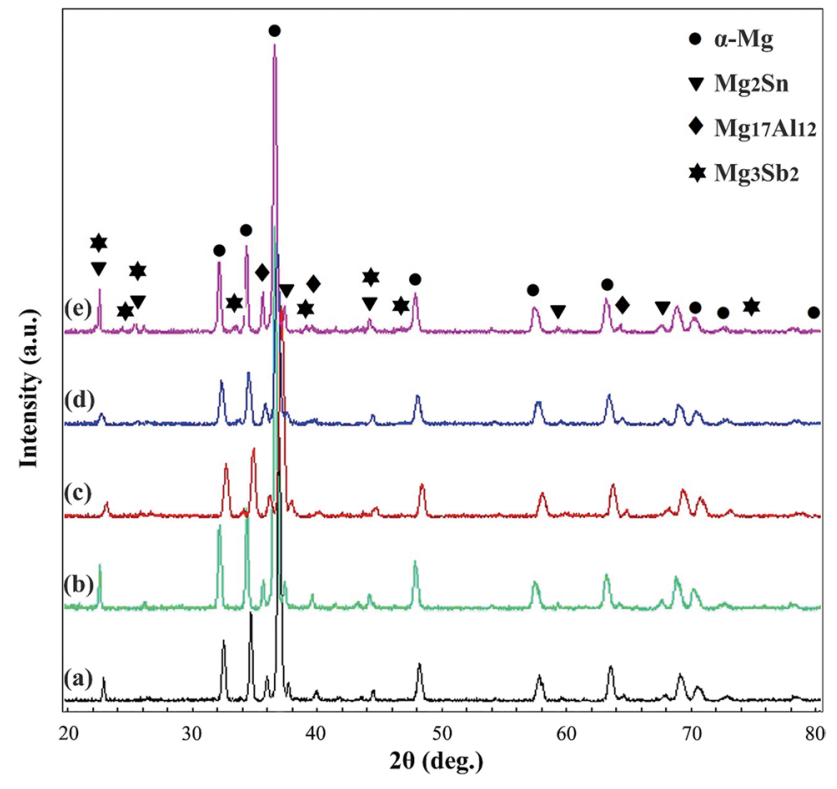

Fig. 2 XRD patterns of the as-cast $\mathrm{Mg}-9 \mathrm{Al}-5 \mathrm{Sn}-x \mathrm{Sb}$ alloys: a $x=0.0, \mathbf{b} x=0.3, \mathbf{c} x=0.6, \mathbf{d} x=1.0, \mathbf{e} x=1.5$

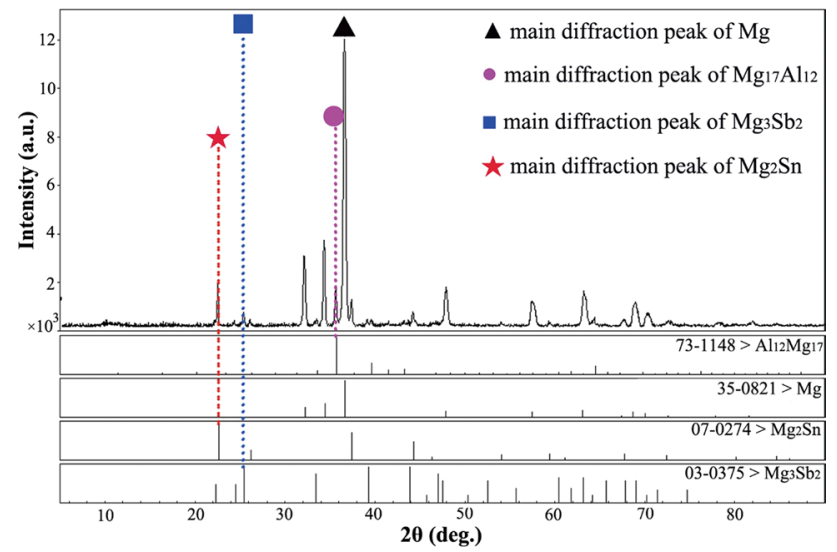

Fig. 3 XRD patterns of the as-cast $5 \#(\mathrm{Mg}-9 \mathrm{Al}-5 \mathrm{Sn}-1.5 \mathrm{Sb})$ alloys

secondary phases with the bright white, white and gray colors exist in the $5 \#$ alloy. Based on the aforementioned $\mathrm{XRD}$ and EDS analysis results, the dark phase is $\alpha-\mathrm{Mg}$ phase, the gray is $\mathrm{Mg}_{17} \mathrm{Al}_{12}$, the white is $\mathrm{Mg}_{2} \mathrm{Sn}$ and the bright white is $\mathrm{Mg}_{3} \mathrm{Sb}_{2}$ phase. The tested compositions of the $\mathrm{Mg}_{2} \mathrm{Sn}$ phase are 66.86 at. $\% \mathrm{Mg}-4.39$ at.\% Al-24.32 at. $\% \mathrm{Sn}-4.53$ at. $\% \mathrm{Sb}$, the compositions of the $\mathrm{Mg}_{3} \mathrm{Sb}_{2}$ phase are 61.28 at. $\% \mathrm{Mg}-1.47$ at. $\% \mathrm{Al}-5.40$ at.\% $\mathrm{Sn}-31.85$ at. $\% \mathrm{Sb}$, and the compositions of the $\mathrm{Mg}_{17} \mathrm{Al}_{12}$ phase are 66.55 at. $\% \mathrm{Mg}-32.34$ at. $\% \mathrm{Al}-0.94$ at. $\% \mathrm{Sn}-0.17$ at. $\% \mathrm{Sb}$ (Fig. 4c). From the above data, it can be seen that the EDS analysis is consistent with the XRD analysis for the as-cast $5 \#$ alloys.

\subsection{Microstructures of As-Extruded Mg-9AI-5Sn- xSb Alloys}

Figures 5 and 6 show the microstructures of as-extruded $\mathrm{Mg}-9 \mathrm{Al}-5 \mathrm{Sn}-x \mathrm{Sb}$ alloy in the longitudinal direction. The volume fraction of secondary phases increases with the content of $\mathrm{Sb}$ increasing. The microstructures of alloys with different $\mathrm{Sb}$ contents are obviously different. After extrusion, $\mathrm{Sb}$-free $\mathrm{Mg}-9 \mathrm{Al}-5 \mathrm{Sn}$ alloy possesses more relatively coarse unrecrystallized grains, indicating that the dynamic recrystallization was not complete. With the addition of $\mathrm{Sb}$ into the $\mathrm{Mg}-9 \mathrm{Al}-5 \mathrm{Sn}$ alloys, the grains become smaller. However, the coarse unrecrystallized grains still exist in the Sb-containing magnesium alloy. Until adding $1.5 \mathrm{wt} \% \mathrm{Sb}$, the microstructure of $\mathrm{Mg}-9 \mathrm{Al}-5 \mathrm{Sn}-1.5 \mathrm{Sb}$ shows the complete recrystallization. The addition of $\mathrm{Sb}$ can significantly refine grains of $\mathrm{Mg}-\mathrm{Al}-\mathrm{Sn}$ alloy. The alloy with $1.5 \mathrm{wt} \% \mathrm{Sb}$ has the smallest grains.

After extrusion, the grains were extremely refined in the longitudinal direction. The grain size reduced obviously with the content of $\mathrm{Sb}$ increasing. A number of blocky compounds in the matrix increase with the increment in the content of Sb. The second phase particles with different sizes were randomly distributed on the longitudinal section (shown in Fig. 5). With the addition of Sb, the particles become finer. Their aspect ratio reduces.

In the alloys with low content of $\mathrm{Sb}$, the dynamic recrystallization was not complete after hot extrusion. With the increment of Sb content, the fraction of unrecrystallized grains decreases. Compared with those as-cast alloys, the grain sizes of as-extruded alloys were considerably smaller. EDS analysis results reveal that the blocky compounds in the extruded stringers are $\mathrm{Mg}_{17} \mathrm{Al}_{12}$ and $\mathrm{Mg}_{2} \mathrm{Sn}$ phase.

\subsection{Texture Formation and TEM Observations}

Figure 7 shows the (0002) and (1010) macrotexture of the 1\# and $4 \#$ extruded alloys. The maximum basal texture intensity decreases from 2.55 to 2.25 with increasing the content of $\mathrm{Sb}$ from 0 to 1.0. The addition of $\mathrm{Sb}$ element can weaken the texture of the $\mathrm{Mg}-\mathrm{Al}-\mathrm{Sn}$ alloy. Previous researches demonstrate that the texture can be effectively weakened by adding rare earth elements [60]. The responsible reason is due to the preferential nucleation at local shear bands and the random orientation of the recrystallization grains [61, 62]. Another view is that the texture weakening is due to solid solution mechanism in $\mathrm{Mg}-\mathrm{RE}$ alloys by which the grain boundary migration is inhibited and non-basal slip is activated [63, 64]. It has been reported by the literature [65], that compared with the cubic structure metals such as $\mathrm{Al}$ and $\mathrm{Fe}$, the influence factors of the texture of hexagonal magnesium alloy are complex, mainly including alloy composition, process and so on. One of the main factors affecting the texture is the 


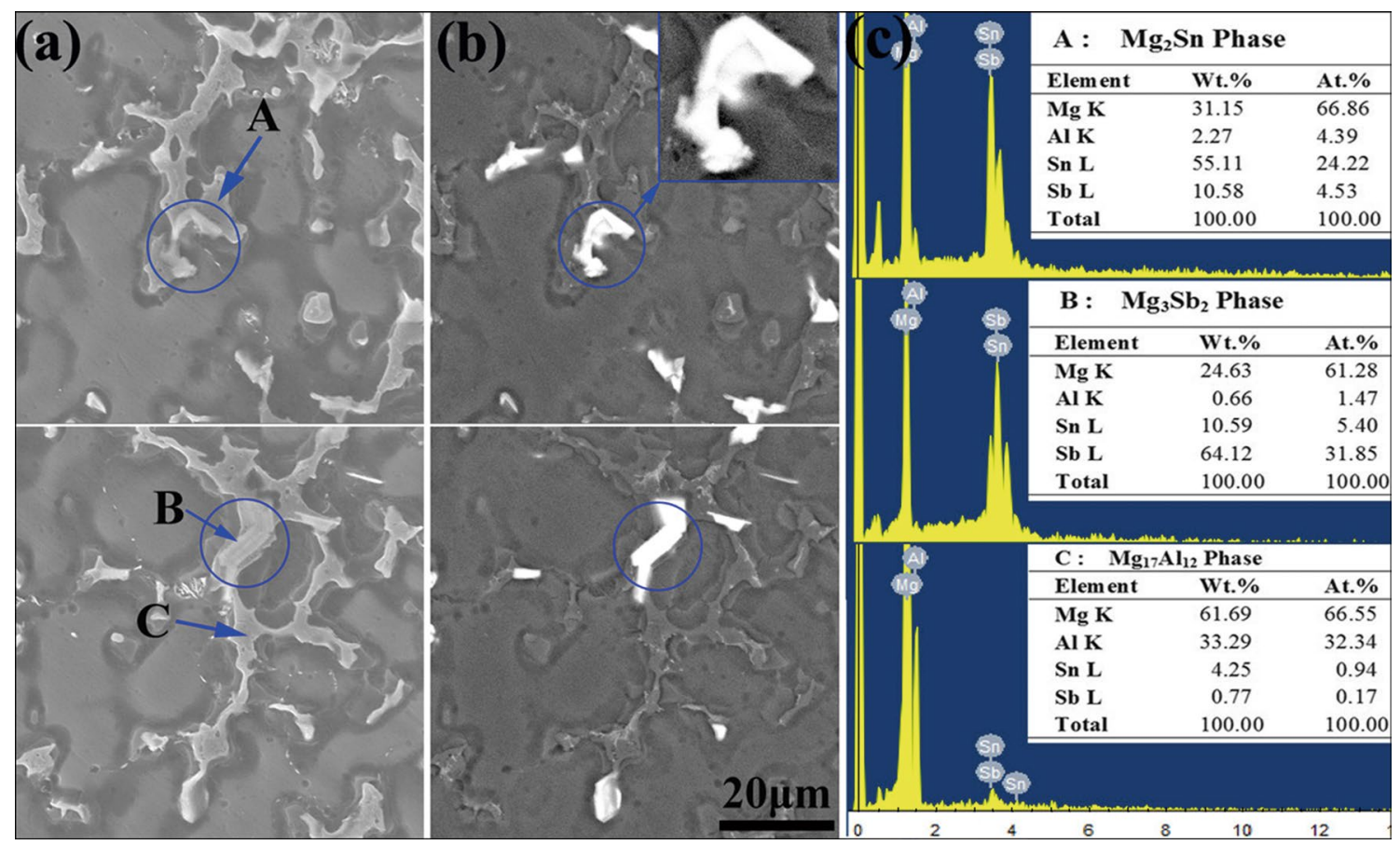

Fig. 4 BSE images of the as-cast alloy 5\# (Mg-9Al-5Sn-1.5Sb): a SEM image; b BSE images; $\mathbf{c}$ the corresponding EDX results of Mg-Al-SnSb phase in a
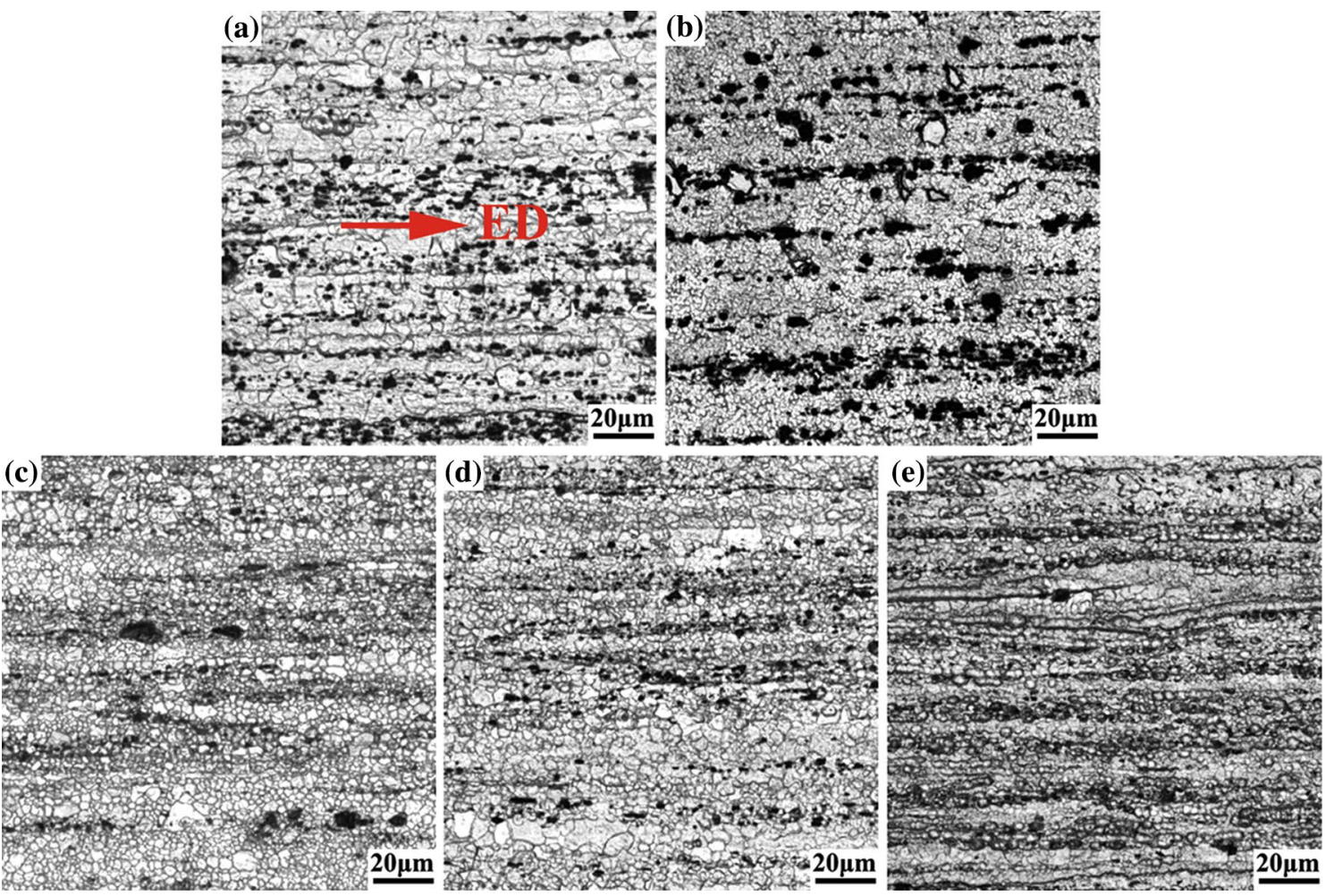

Fig. 5 Optical micrographs of Mg-9Al-5Sn-xSb alloy extruded parallel to the extrusion direction: a $1 \#: x=0.0 ; \mathbf{b} 2 \#: x=0.3$; $\mathbf{c} 3 \#: x=0.6$; d $4 \#: x=1.0 ; \mathbf{e} 5 \#: x=1.5$ 

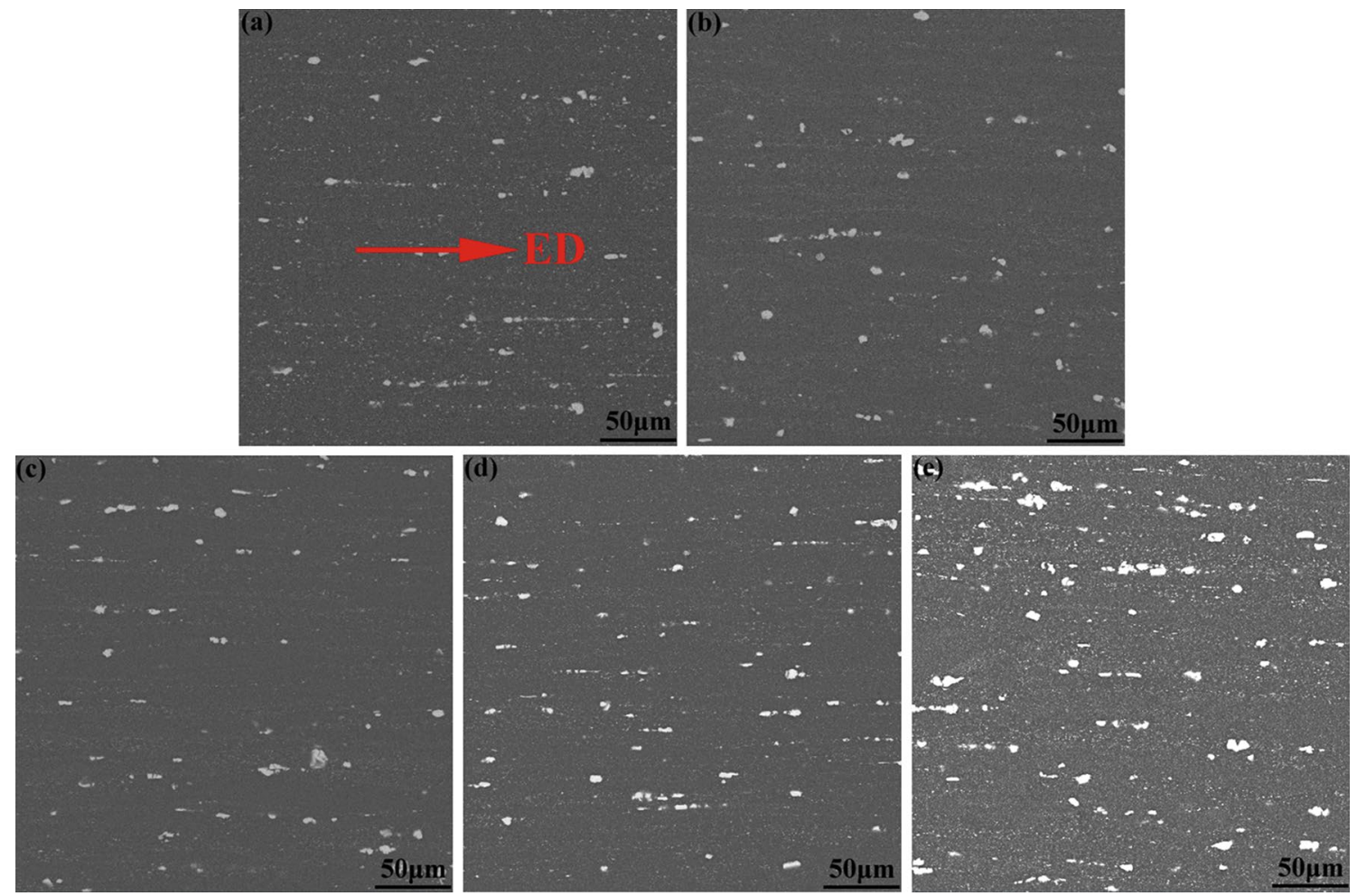

Fig. 6 SEM micrographs of as-extruded Mg-9Al-5Sn- $x$ Sb alloys: a $x=0.0 ; \mathbf{b} x=0.3 ; \mathbf{c} x=0.6 ; \mathbf{d} x=1.0$; and e $x=1.5$

composition of alloying elements. The change of the solid solutions composition could result in the change of lattice constant of the matrix, which changes the texture. The quantitative analysis of XRD data shows that the lattice parameters of 1\# alloy are $a=3.1730, c=5.1657, c / a=1.6280$; the lattice parameters of $4 \#$ alloy are $a=3.1866, c=5.1774$; $c / a=1.6247$. The addition of Sb changes the lattice parameters of magnesium matrix, which reduces the value of $c / a$, the reduction in the axial ratio will change the density of close-packed crystal surface, which will activate the nonbasal planes slip on the basis of the slip of the basal plane, thus reducing the texture of the alloy and improving the properties of the alloy.

Figure 8 shows TEM images of the as-extruded alloy 4\# (Mg-9Al-5Sn-1.0Sb). TEM observations indicated that this alloy contains several second phases $\mathrm{Mg}_{3} \mathrm{Sb}_{2}, \mathrm{Mg}_{2} \mathrm{Sn}$ and $\mathrm{Mg}_{17} \mathrm{Al}_{12}$. The particle indicated by an orange arrow is composed of $\mathrm{Mg}, \mathrm{Al}, \mathrm{Sn}$ and $\mathrm{Sb}$. Its EDS spectrum shows prominent $\mathrm{Mg}$ and $\mathrm{Sn}$ peaks. The content of $\mathrm{Al}$ and $\mathrm{Sb}$ is low in this particle. Its composition is 65.73 at. $\% \mathrm{Mg}-0.57$ at.\% Al-32.63 at.\% Sn-1.07 at.\% Sb (Fig. 8d). Its corresponding selected area electron diffraction (SAED) pattern can be indexed as the $\mathrm{Mg}_{2} \mathrm{Sn}$ phase with a face-centered cubic structure $(a=0.6765 \mathrm{~nm})$ (Fig. 8c). Figure 9 presents the dark field TEM image and the EDS mappings of $\mathrm{Mg}, \mathrm{Al}, \mathrm{Sn}$ and $\mathrm{Sb}$ elements. The $\mathrm{Mg}-9 \mathrm{Al}-5 \mathrm{Sn}-1.0 \mathrm{Sb}$ alloy composed of the $\mathrm{Mg}_{17} \mathrm{Al}_{12}, \mathrm{Mg}_{3} \mathrm{Sb}_{2}$ and $\mathrm{Mg}_{2} \mathrm{Sn}$ phases in the primary $\alpha$-Mg matrix.

\subsection{Mechanical Properties of As-Extruded Mg-9AI- $5 \mathrm{Sn}-\mathrm{xSb}$ Alloys}

The typical tensile engineering stress-strain curves of the as-extruded $\mathrm{Mg}-9 \mathrm{Al}-5 \mathrm{Sn}-x \mathrm{Sb}$ alloys are shown in Fig. 10a. The data of mechanical properties are shown in Fig. 10b. The tensile properties of extruded alloys are summarized in Table 2. It is demonstrated that the ultimate tensile strength, yield strength and elongation are affected by the content of $\mathrm{Sb}$. When the content of $\mathrm{Sb}$ reaches to $0.3 \mathrm{wt} \%, 0.6 \mathrm{wt} \%, 1.0$ $\mathrm{wt} \%$ and $1.5 \mathrm{wt} \%$, the ultimate tensile strength is increased by $3 \%, 5 \%, 10 \%$ and $4.7 \%$, respectively. The elongation is decreased by $2.8 \%, 16 \%$ and $15.6 \%$, respectively, except for $2 \#$ alloy with increasing by $20 \%$. However, no obvious change in the yield strength was found with the addition of Sb. Sb-free alloy exhibited an ultimate tensile strength (UTS) of $339 \mathrm{MPa}$, a yield strength (YS) of $249 \mathrm{MPa}$ and an elongation (EL) of $4.61 \%$. The addition of small amount of $\mathrm{Sb}(0.3$ and $1.0 \mathrm{wt} \%)$ significantly improved the yield strength and ultimate tensile strength, but reduced the elongation a little. The addition of $1.5 \mathrm{wt} \% \mathrm{Sb}$ substantially reduced the room temperature ductility to $2.78 \%$. The alloy $4 \#$ exhibits the relatively optimal comprehensive mechanical properties. Its ultimate tensile 

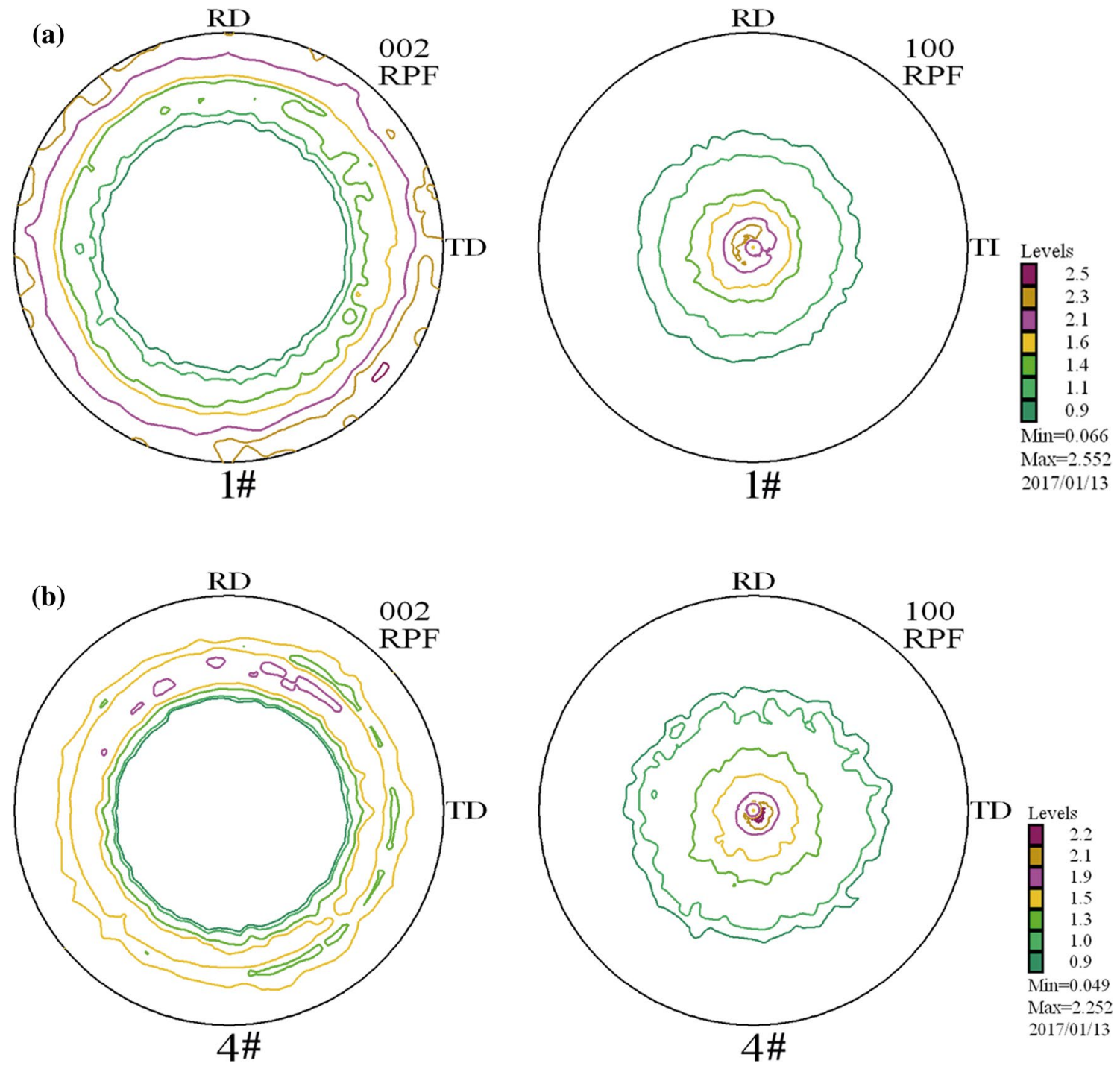

Fig. 7 [0002] and [1010] pole figures of the Mg-9Al-5Sn- $x$ Sb extruded alloys: a 1\# $(x=0.0)$; b 4\# $(x=1.0)$

strength, yield strength and elongation are $373 \mathrm{MPa}, 262 \mathrm{MPa}$ and $3.86 \%$, respectively. It can be concluded that $\mathrm{Sb}$ addition significantly increases the strength of $\mathrm{Mg}-\mathrm{Al}-\mathrm{Sn}$ alloy, meanwhile severely deteriorates the ductility. When $\mathrm{Sb}$ addition reaches $1.0 \mathrm{wt} \%$, the properties of the alloy are optimized. However, when the content of Sb exceeds $1.0 \mathrm{wt} \%$, the UTS of the $\mathrm{Mg}-9 \mathrm{Al}-5 \mathrm{Sn}-1.5 \mathrm{Sb}$ is $355 \mathrm{MPa}$, which is a little lower than the elongation of $\mathrm{Mg}-9 \mathrm{Al}-5 \mathrm{Sn}-1.0 \mathrm{Sb}$. As a result, adding a certain amount of $\mathrm{Sb}$ can improve the comprehensive mechanical properties of the Mg-9Al-5Sn alloy.

\section{Conclusions}

The effects of $\mathrm{Sb}$ addition on the microstructure and mechanical properties of the $\mathrm{Mg}-9 \mathrm{Al}-5 \mathrm{Sn}$ alloy have been investigated. The following conclusions can be drawn:

1. With the addition of $\mathrm{Sb}$, the grains of the cast and extruded $\mathrm{Mg}-9 \mathrm{Al}-5 \mathrm{Sn}-x \mathrm{Sb}(x=0.0,0.3,0.6,1.0,1.5)$ 

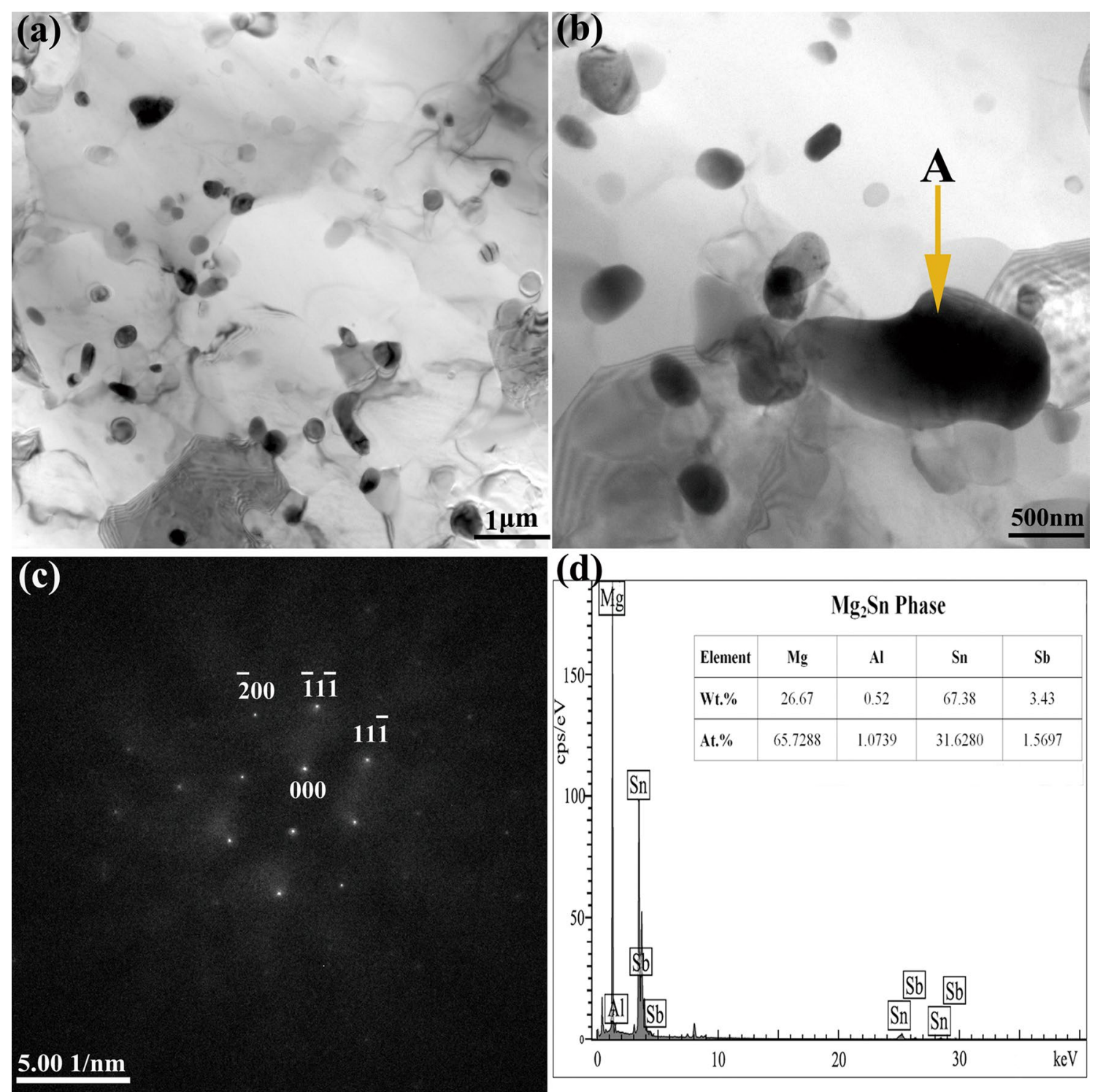

Fig. 8 TEM images of extruded $\mathrm{Mg}-9 \mathrm{Al}-5 \mathrm{Sn}-1.0 \mathrm{Sb}$ alloy: a bright field image of precipitates; $\mathbf{b}$ a representative $\mathrm{Mg}_{2} \mathrm{Sn}$ particle; $\mathbf{c}$ the corresponding selected area electron diffraction (SAED) pattern recorded from particle indicated by orange arrow in Fig. $8 \mathrm{~b}$; $\mathbf{d}$ the corresponding EDX results of $\mathrm{Mg}_{2} \mathrm{Sn}$ phase in Fig. $8 \mathrm{~b}$

alloys are refined. The second phases in the as-cast alloys include $\mathrm{Mg}_{2} \mathrm{Sn}, \mathrm{Mg}_{17} \mathrm{Al}_{12}$ and $\mathrm{Mg}_{3} \mathrm{Sb}_{2}$.

2. The $\mathrm{Mg}_{2} \mathrm{Sn}$ phase in the as-extruded $\mathrm{Mg}-9 \mathrm{Al}-5 \mathrm{Sn}-$ $x \mathrm{Sb}$ alloy has a spherical or plate-like morphology. The $\mathrm{Mg}_{2} \mathrm{Sn}$ phase has a face-centered cubic structure with lattice parameter $a=0.6765 \mathrm{~nm}$.

3. The addition of $\mathrm{Sb}$ can weaken slightly the texture of the as-extruded Mg-9Al-5Sn alloy, to some extent. With increasing Sb content, the maximum texture intensity decreases from 2.55 to 2.25 .

4. With the increasing of $\mathrm{Sb}$ content, the ultimate tensile strength increases gradually. When $\mathrm{Sb}$ content reaches to $1.0 \mathrm{wt} \%$, the performance is the best. The ultimate tensile strength (UTS), yield strength (YS) and elongation (EL) of the 4\# alloy are $373 \mathrm{MPa}, 262 \mathrm{MPa}$ and 3.86\%, respectively. 

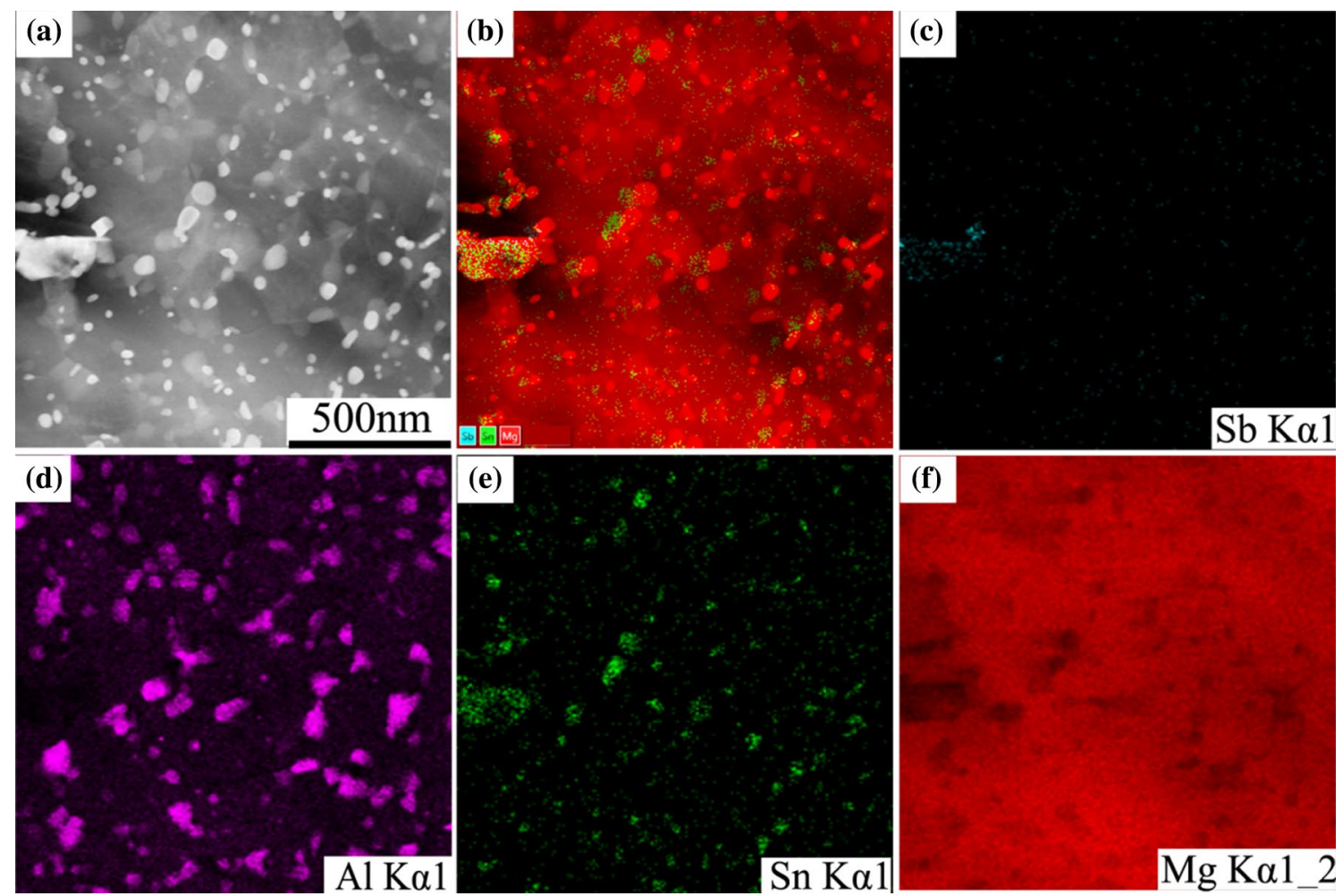

Fig. 9 TEM images of extruded Mg-9Al-5Sn-1.0Sb alloy along with the corresponding EDS mappings of $\mathrm{Mg}, \mathrm{Al}, \mathrm{Sn}$ and $\mathrm{Sb}$ elements distribution of the precipitate. a Bright field image; b EDS mapping of element $\mathrm{Mg}$, Sn and $\mathrm{Sb} ; \mathbf{c} \mathrm{Sb} ; \mathbf{d ~ A l} ; \mathbf{e ~ S n ; ~} \mathbf{f ~ M g}$
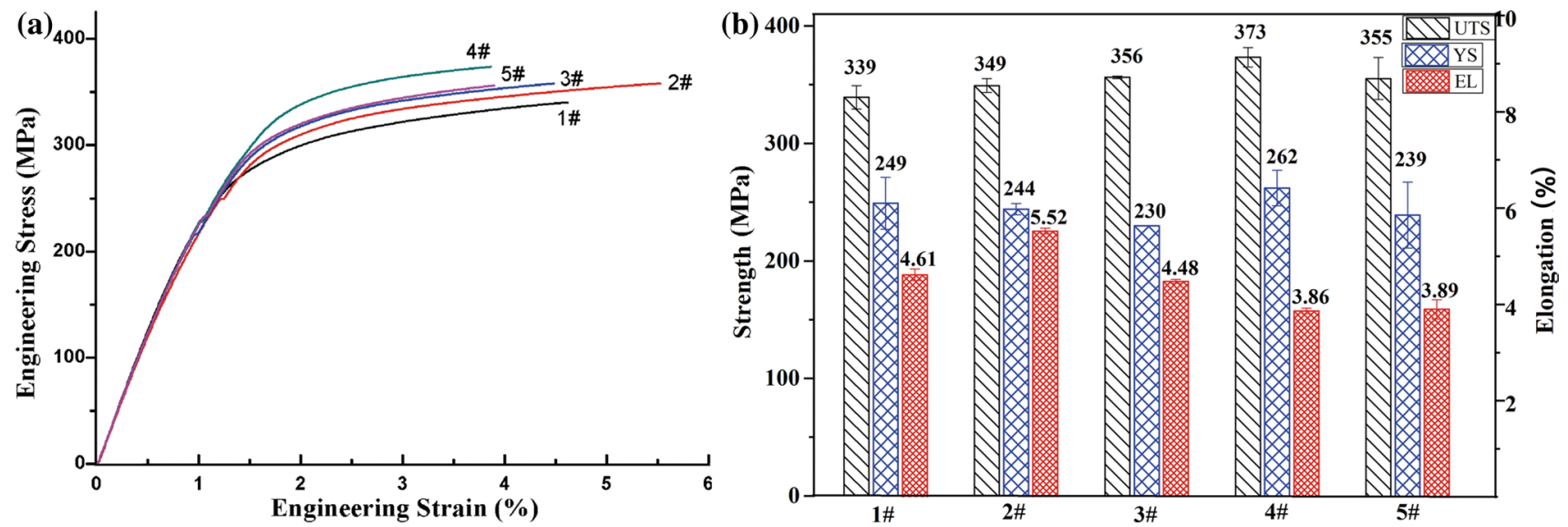

Fig. 10 a Nominal stress-nominal strain curves of as-extruded $\mathrm{Mg}-9 \mathrm{Al}-5 \mathrm{Sn}-x \mathrm{Sb}$ alloys and $\mathbf{b}$ tensile properties of the $\mathrm{Mg}-9 \mathrm{Al}-5 \mathrm{Sn}-x \mathrm{Sb}$ samples extruded at $300^{\circ} \mathrm{C}$ 
Table 2 Mechanical properties of $\mathrm{t}$ as-extruded $\mathrm{Mg}-9 \mathrm{Al}-5 \mathrm{Sn}-x \mathrm{Sb}$ alloys

\begin{tabular}{lllll}
\hline Code & Alloys & UTS (MPa) & YS (MPa) & EL (\%) \\
\hline 1\# & Mg-9Al-5Sn-0.0Sb & 339 & 249 & 4.61 \\
2\# & Mg-9Al-5Sn-0.3Sb & 349 & 244 & 5.52 \\
3\# & Mg-9Al-5Sn-0.6Sb & 356 & 230 & 4.48 \\
$4 \#$ & Mg-9Al-5Sn-1.0Sb & 373 & 262 & 3.86 \\
5\# & Mg-9Al-5Sn-1.5Sb & 355 & 239 & 3.89 \\
\hline
\end{tabular}

Acknowledgements This work was financially supported by the National Natural Science Foundation of China (Nos. 51531002 and 51571040), the National Great Theoretic Research Project (No. 2013CB632200), the National Great Engineering Research Project (No. 2016YFB0301101), the Ministry of Education of China (No. SRFDR 20130191110018) and the Chongqing Municipal Government (No. CSTC2013JCYJC60001, CEC Project, Two River Scholar Project and The Chief Scientist Studio Project) and the Fundamental Research Funds for the Central universities (No. 106112016CDJXZ138811), the Science and Technology Key Projects of Henan Province (No. 172102210425)

\section{References}

[1] H. Jafari, E. Heidari, A. Barabi, M.D. Kheirabadi, Acta Metall. Sin. Engl. Lett. 31, 561 (2018)

[2] S.H. You, Y.D. Huang, K.U. Kainer, N. Hort, J. Magn. Alloys 5, 239 (2017)

[3] T. Tu, X.H. Chen, J. Chen, C.Y. Zhao, F.S. Pan, Acta Metall. Sin. Engl. Lett. 32, 23 (2019)

[4] B.Y. Qian, W. Miao, M. Qiu, F. Gao, D.H. Hu, J.F. Sun, R.Z. Wu, B. Krit, S. Betsofen, Acta Metall. Sin. Engl. Lett. 32, 194 (2019)

[5] K. Yang, J.S. Zhang, X.M. Zong, W. Liu, C.X. Xu, Acta Metall. Sin. Engl. Lett. 30, 464 (2017)

[6] C. Liu, H. Chen, C. He, Y. Zhang, J.F. Nie, Mater. Charact. 113, 214 (2016)

[7] X. Fu, Y. Yang, J. Hu, J. Su, X. Zhang, X. Peng, Mater. Sci. Eng. A 709, 247 (2018)

[8] J. Zhang, S. Liu, R. Wu, L. Hou, M. Zhang, J. Magn. Alloys 6, 277 (2018)

[9] X.J. Wang, D.K. Xu, R.Z. Wu, X.B. Chen, Q.M. Peng, L. Jin, Y.C. Xin, Z.Q. Zhang, Y. Liu, X.H. Chen, G. Chen, K.K. Deng, H.Y. Wang, J. Mater. Sci. Technol. 34, 245 (2018)

[10] H. Zhou, H.Y. Ning, X.L. Ma, D.D. Yin, L.R. Xiao, X.C. Sha, Y.D. Yu, Q.D. Wang, Y.S. Li, J. Mater. Sci. Technol. 34, 1067 (2018)

[11] A.M. Majd, M. Farzinfar, M. Pashakhanlou, M.J. Nayyeri, J. Magn. Alloys 6, 309 (2018)

[12] W.Y. Han, G.Y. Yang, L. Xiao, J.H. Li, W.Q. Jie, Mater. Sci. Eng. A 684, 90 (2017)

[13] N. El Mahallawy, A. Ahmed Diaa, M. Akdesir, H. Palkowski, Mater. Sci. Eng. A 680, 47 (2017)

[14] C.H. Ma, Z.W. Lu, Z.G. Zhong, Y.M. Leng, T. Ye, Y.Z. Zhao, J.B. He, J. Phase Equilib. Diffus. 39, 800 (2018)

[15] E.Y. Liu, S.R. Yu, M. Yuan, F.G. Li, Y. Zhao, W. Xiong, Acta Metall. Sin. Engl. Lett. 31, 953 (2018)

[16] Z.Y. Jin, N.N. Li, K. Yan, J. Wang, J. Bai, H.B. Dong, Acta Metall. Sin. Engl. Lett. 31, 71 (2018)

[17] T.Z. Han, G.S. Huang, L. Huang, B. Jiang, G.G. Wang, A.T. Tang, F.S. Pan, Acta Metall. Sin. Engl. Lett. 31, 225 (2018)

[18] P.P. Wu, K.K. Deng, K.B. Nie, Z.Z. Zhang, Acta Metall. Sin. Engl. Lett. 32, 218 (2019)
[19] K. Sheng, L.W. Lu, Y. Xiang, M. Ma, Z.C. Wang, Acta Metall. Sin. Engl. Lett. 32, 235 (2019)

[20] G. Liu, L.N. Ma, Z.D. Ma, X.S. Fu, G.B. Wei, Y. Yang, T.C. Xu, W.D. Xie, X.D. Peng, Acta Metall. Sin. Engl. Lett. 31, 853 (2018)

[21] Y. Wu, Y.C. Xin, X.S. Xia, B. Feng, Y.B. Wang, Z.D. Zhao, Acta Metall. Sin. Engl. Lett. 32, 227 (2019)

[22] Q.F. Zhu, G.S. Wang, E.G. Zhang, F.Z. Liu, Z.Q. Zhang, J.Z. Cu, Acta Metall. Sin. Engl. Lett. 30, 941 (2017)

[23] Y. Dai, X.H. Chen, T. Yan, A.T. Tang, D. Zhao, Z. Luo, C.Q. Liu, R.J. Cheng, F.S. Pan, Acta Metall. Sin. Engl. Lett. 33, 225 (2019)

[24] D.H. Hou, S.M. Liang, R.S. Chen, C. Dong, E.H. Han, Acta Metall. Sin. Engl. Lett. 28, 115 (2014)

[25] A.K.S. Bankoti, A.K. Mondal, H. Dieringa, B.C. Ray, S. Kumar, Mater. Sci. Eng. A 673, 332 (2016)

[26] A. Srinivasan, J. Swaminathan, M.K. Gunjan, U.T.S. Pillai, B.C. Pai, Mater. Sci. Eng. A 527, 1395 (2010)

[27] G.Y. Yuan, Z.L. Liu, Q.D. Wang, W.J. Ding, Mater. Lett. 56, 53 (2002)

[28] A. Srinivasan, U.T.S. Pillai, B.C. Pai, Metall. Mater. Trans. A 36, $2235(2005)$

[29] Y. Bai, W.L. Cheng, S.C. Ma, J. Zhang, C. Guo, Y. Zhang, Acta Metall. Sin. Engl. Lett. 31, 487 (2017)

[30] Z.Y. Zhao, R.G. Guan, J.H. Zhang, Z.Y. Zhao, P.K. Bai, Acta Metall. Sin. Engl. Lett. 30, 66 (2017)

[31] R. Rajeshkumar, J. Jayaraj, A. Srinivasan, U.T.S. Pillai, J. Alloys Compd. 691, 81 (2017)

[32] N. Balasubramani, A. Srinivasan, U.T.S. Pillai, B.C. Pai, Mater. Sci. Eng. A 457, 275 (2007)

[33] G.Y. Yuan, Z.L. Liu, Q.D. Wang, W.J. Ding, Scr. Mater. 43, 1009 (2000)

[34] S.H. Park, J.G. Jung, Y.M. Kim, B.S. You, Mater. Lett. 139, 35 (2015)

[35] B. Zhou, D. Wu, R.S. Chen, E.H. Han, J. Mater. Sci. Technol. 35, $1860(2019)$

[36] Q. Jiang, X. Lv, D. Lu, J. Zhang, B. Hou, J. Magn. Alloys 6, 346 (2018)

[37] Z. Huseyin, T. Yunus, E.T. Muhammet, A. Fatih, Acta Metall. Sin. Engl. Lett. 32, 1309 (2019)

[38] Y.A. Chen, Y. Wang, J. Gao, J. Alloys Compd. 740, 727 (2018)

[39] B.N. Du, Z.Y. Hu, L.Y. Sheng, D.K. Xu, Y.F. Zheng, T.F. Xi, Acta Metall. Sin. Engl. Lett. 31, 351 (2018)

[40] P. Poddar, A. Kamaraj, A.P. Murugesan, S. Bagui, K.L. Sahoo, J. Magn. Alloys 5, 348 (2017)

[41] E. Karakulak, Y.B. Küçüker, J. Magn. Alloys 6, 384 (2018)

[42] C.H. Ma, D.F. Zhang, Y.H. Fan, F.G. Qi, J.Q. Li, J. Phase Equilib. Diffus. 34, 9 (2012)

[43] Q. Zhao, Y. Wu, W. Rong, K. Wang, L. Yuan, X. Heng, L. Peng, J. Magn. Alloys 6, 197 (2018)

[44] W. Du, K. Liu, K. Ma, Z. Wang, S. Li, J. Magn. Alloys 6, 1 (2018)

[45] X. Shi, Y. Li, X. Zeng, Y. Liu, B. Chen, J. Lu, D. Li, J. Mater. Sci. Technol. 35, 1473 (2019)

[46] P.L. Zhang, Y.H. Zhao, R.P. Lu, Z.B. Ding, H. Hou, Acta Metall. Sin. Engl. Lett. 32, 550 (2018)

[47] H.Y. Wang, T.T. Feng, L. Zhang, C.G. Liu, Y. Pan, M. Zha, X.L. Nan, C. Wang, Q.C. Jiang, Mater. Des. 88, 157 (2015)

[48] H. Khalilpour, S. Mahdi Miresmaeili, A. Baghani, Mater. Sci. Eng. A 652, 365 (2016)

[49] B. Wang, F.S. Pan, X.H. Chen, W. Guo, J.J. Mao, Mater. Sci. Eng. A 656, 165 (2016)

[50] C.Q. Liu, C.L. Liu, H.W. Chen, J.F. Nie, J. Mater. Sci. Technol. 34, 284 (2018)

[51] G. Nayyeri, R. Mahmudi, Mater. Sci. Eng. A 527, 669 (2010)

[52] H. Liu, Y. Chen, H. Zhao, S. Wei, W. Gao, J. Alloys Compd. 504, 345 (2010)

[53] A.M. Jamili, A. Zarei Hanzaki, H.R. Abedi, P. Minárik, R. Soltani, Mater. Sci. Eng. A 690, 244 (2017) 
[54] X. Fang, S. Lü, L. Zhao, J. Wang, L. Liu, S. Wu, Mater. Des. 94, 353 (2016)

[55] J.L. Wu, L. Jin, J. Dong, F.H. Wang, S. Dong, J. Mater. Sci. Technol. 42, $175(2020)$

[56] N. Stanford, Mater. Sci. Eng. A 528, 314 (2010)

[57] Materials Data JADE Release 5, XRD Pattern Processing, Materials Data Inc. (MDI) (2002)

[58] Powder Diffraction File, International Center for Diffraction Data (2002)

[59] H.X. Wang, K.K. Zhou, G.Y. Xie, X.Z. Liang, W. Liang, Y.T. Zhao, Mater. Sci. Eng. A 560, 787 (2013)
[60] N. Tahreen, D.F. Zhang, F.S. Pan, X.Q. Jiang, D.Y. Li, D.L. Chen, J. Mater. Sci. Technol. 31, 1161 (2015)

[61] S.H. Kim, J.G. Jung, B.S. You, S.H. Park, J. Alloys Compd. 695, 344 (2017)

[62] Q. Liu, Acta Metall. Sin. 46, 1458 (2010). (in Chinese)

[63] N. Tahreen, D.F. Zhang, F.S. Pan, X.Q. Jiang, D.Y. Li, D.L. Chen, J. Alloys Compd. 688, 270 (2016)

[64] J.P. Hadorn, K. Hantzsche, S. Yi, J. Bohlen, D. Letzig, J.A. Wollmershauser, S.R. Agnew, Metall. Mater. Trans. A 43, 1347 (2012)

[65] Z.H. Chen, W.J. Xia, Y.Q. Chen, D.F. Fu, Chin. J. Nonferrous Met. 15, $1(2005)$ 